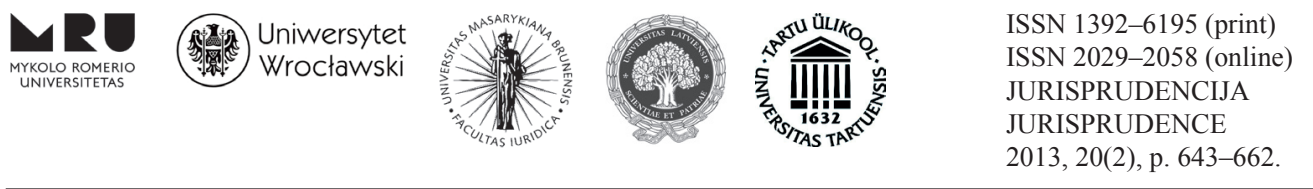

\title{
THE ROOTS OF FRENCH WELFARE STATE
}

\author{
Fabien Bottini \\ Le Havre University, Faculty of International Affairs, \\ Department of Law \\ 25, rue Philippe Lebon, 76063 Le Havre Cedex \\ Telephone: (+33 02) 32744126 \\ E-mail: fabien.bottini@univ-lehavre.fr \\ Received on 27 May, 2013; accepted on 24 August, 2013 \\ doi:10.13165/JUR-13-20-2-15
}

\begin{abstract}
In this article the author tries to answer the difficult question of the roots of the welfare state. The study of the French example shows that if some roots are ideological, at the same time they are sociological, too. In the article the main streams of ideological roots are described and conclusion is drawn that nowadays sociological issues are very important. The popularity of the welfare state shows that dismantlement is impossible in the democratic States. Yet, its crisis due to its cost in a globalized world asks the question of the balance point between the fight against assistantship and maintenance of the redistributive nature of the welfare state. The answer to that question still remains the key challenge for European politicians.
\end{abstract}

Keywords: State Constable, Welfare State, État-providence, Social State, Redistributive State, Social rights. 


\section{Introduction}

Robert Jacques Turgot (1721-1781) wrote: "Humanity, religion oblige us to relieve our fellow men." If this duty makes a consensus, its terms are subject to debate. It also raises questions such as how can this help be achieved? Should it be provided by the State or not?

In 1893, the French representative Leon Say (1826-1896) answered the abovestated questions in the negative. He denounced the interference of the State in the economy in the name of solidarity. He saw "the worst of the socialisms, a bourgeois socialism" in it. Some eminent French jurists relayed this criticism, e.g., a few years later, Maurice Hauriou (1856-1929) declared to regret it: "We say it is serious, because our State has been changed"1.

These personalities condemned the transformation of the State constable into the welfare state.

Due to the rallying of politicians to liberal dogma, the State constable is characterized in the 1890 s by a limited intervention of public power. Its action is indeed confined to the regulatory functions necessary for the good work of the free market: coining money and ensuring transaction security (justice and police inside; diplomacy and national defense outside).

On the contrary, the development of the welfare state leads to a greater intervention of public power in the economic sector.

It is the French representative Émile Ollivier (1825-1913) who forged the French expression of Etat-providence that can be translated into "welfare state". He forged it in 1864 in a pejorative sense to condemn the claim of the government to substitute a "welfare state" to the "Divine Providence". Pope Leo XIII cried in 1891: "Do not appeal to the welfare state because the state is after the man. Before it was formed, the man had already received from nature the right to live and protect its own existence." 2

This is what the Church calls the "Divine Providence", an expression referring to dispositions by which God guides his creation towards its ultimate goal that is perfection. The most famous manifestation of this "Divine Providence" is Jesus Christ because Catholicism teaches that God sent him as a gift for the men to be led to salvation'.

But what characterizes the welfare state? The aim of this article is to show that it is characterized not so much by its intervention in the socio-economy, which is the goal of this intervention. A study of the positive law inlighted by a historical approach and a study of its ideological foundations show that it aims to ensure a fair redistribution of wealth to fight against poverty, i.e. to help anyone who cannot live only of the resources of his work. Because of its religious connotation, the French concept of Etat-providence is sometimes questioned. Some prefer the term of "social State" or of "redistributive

1 Note under TC 9.12.1899, Assoc. synd. du canal de Gignac. Paris: Dalloz, 1899 (3): 50.

2 Rerum Novarum. May $15^{\text {th }}, 1891$.

3 Lacroix, P. What is the Divine Providence. City of the Father. October-November, 2005. 
State" that seems more consistent with the secular nature of that assistance to the poor. But the fact is that its popular foundations make (UNFINISHED SENTENCE).

This intervention takes place in practice with the recognition of certain social rights to individuals, i.e., rights they may require the State to set up. The main rights relate to the establishment of a welfare system, by which society supports the risks of disease, old age, unemployment or family. Other social rights, however, can also be assigned to promote access to education or housing. The important thing is that these different rights are considered to be complementary. If it is necessary to fight against the disease or professional risks, it is because they are synonymous with unemployment for the individual and, therefore, loss of income for him and his family. Similarly, if it is necessary to educate the masses, it is to allow them to escape to their social status by improving their income. Finally, social housing aims to improve hygiene and to fight certain diseases which could cause mortality or certain work disabilities, such as tuberculosis.

This overall coherence shows that the welfare state is an "instrument of national solidarity." It "is the born defender of the poor, the unfortunate victim of social fate" because "only it has (...) the authority to impose collective duties and assign obligations to each people". Its originality is to exploit the legal system in order to collectivize risks to members of society and thus to protect everyone. Through this "interventionist right" (N. Luhmann) the State becomes "propulsion"': it interferes in the economy "to achieve true equality, rather than formal, in the name of the imperative of social justice" Its $^{\text {. }}$ development is linked to the rise of socialist ideas even if it is not identical with them. More precisely, we can indeed say that its appearance was prepared by the largest ideological evolutions even if it appeared primarily as a sociological reality.

\section{Ideological Foundations of the Welfare State}

The advent of the welfare state finds its source in philosophical-religious and political-economic considerations.

\subsection{The Religious and Philosophical Foundation of the Welfare State}

\subsubsection{The Religious Foundations: Christianity}

The duty of assistance that characterizes the welfare state is founded in the Christian religion. While Catholicism has first justified to entrust the Church with the help of the poor, Protestantism has transferred that duty to the society.

4 JO Ch. Député CR, Session of May $18^{\text {th }}, 1893$, p. 318.

5 Morand, C. A, Weighing GlobalInterests. Bâle: Helbing \& Lichtenhahn, 1996.

6 Chevallier, J. The Post-Modern State. Paris: LGDJ, 2004, p. 23. 


\subsubsection{Catholicism or the Duty of the Church to Help the Poor in the Name of Christian Charity}

Until the early XVIth century, the sacralization of poverty led Catholicism to promote Christian charity, which entrusted the Church with the duty of supporting the disadvantaged. The idea was that the "duty of Christian charity" to help the most disadvantaged" could not be achieved by the action of the law". The root of this duty is found in the following passage of the Gospels, where Jesus says: "What you do to the least of my brothers, you do it to me". The Church "always commented this text by saying that you must not refuse alms" to "a poor creature without fearing refusing it to the Christ himself". Indeed, it is well known that Jesus had a life of suffering.

Of course, the Church does not require the faithful to renounce the goods that are necessary for their livelihood, their families or the lifestyle, as St. Thomas said: "No one must live contrary to conventions" ". But the Gospels invite the faithfuls to give their surplus of wealth to the clergy, so that it can fulfill the will of the Lord. Therefore, "What remains, give it to charity", as it is said in St. Luke (v. 11, 41).

However, this conception of assistance will be challenged by Protestantism.

\subsubsection{Protestantism or the Duty of the Society to Help the Poor in the Name of Beneficence}

In 1517 Martin Luther (1483-1546) began the Reformation. It led to the desacralization of poverty and to the promotion of another conception of charity called beneficence.

This significant change resulted from a new conception of the relation between the men and God. In the eyes of Protestants, Jesus Christ is not only embodied in the most miserable. He is in every man. Therefore, there is no need to give the surplus of your wealth to the Church in order to be worthy in the eyes of the Lord. The most important thing is that you have to be faithful. Thus, one can prove that he has faith by helping the poorest directly. According to this point of view, beneficence reflects a secularization of assistance to the poor, i.e. poverty becomes a social problem before becoming a State policy ${ }^{10}$.

This development marks a major milestone in the development of the welfare state because the secularization of the poor relief will allow the state to substitute Christian charity. While getting rid of the action from the Church, the state will take the responsibility of erasing inequalities by repairing injustices of birth or twists of fate.

Some philosophical theories will encourage this development, as well.

$7 \quad$ Leo XIII. Rerum Novarum. op. cit.

8 Foucault, M. History of Madness. Paris: Plon, 1961, p. 75.

9 St. Thomas. Are theological. II-II, q. 32. 6.

10 Ewald, F. History of the Welfare State. Paris: Grasset, 1986, p. 44. 


\subsubsection{Philosophical Foundations: Ius Naturalis and Marxism}

Philosophical foundations of the welfare state are found in the Ius naturalis and Marxism dogmas.

\subsubsection{Ius Naturalis Dogma}

Contribution to the welfare state of the school established by Grotius is ambiguous. While the goal of the Lockean social contract leads to reject the needy out of the State sphere (A), the Hobbesian social contract orders to bring them back (B).

\subsection{The Lockean Conception of the Social Contract or the Reject of the Poorest out of the State Sphere}

The conception of the Social Contract inherited from John Locke (1632-1704) founded liberal society. According to him, "society cannot help its members" because "by contracting the association (...) each is supposed to bring his livelihood "11. Thus, poor people cannot solicit the State power to improve their fate, since such help is not in the jurisdiction of the authorities.

There are two reasons for that. The first is the belief that helping the poor people is a matter of morality and not of law because the virtues of morality cannot be imposed, as Jourdan stated: "These are things that cannot be ordered, commanded"12. The second results from the desire not to weaken the rule of law.

In addition, two new considerations led the Liberals to refuse to legally oblige the richest to help the poorest. The first consideration is to ensure the effectiveness of the rule of law. The liberals feared that it could become a factor of disintegration of social ties rather than an instrument of pacification of social relations if it imposed a duty of caring to the poorest because it could arouse the hostility of the rich while it fuels the claims of the most disadvantaged. As Duchatel summarized it, in the eyes of liberalism "recognizing the poor's right to alms, it is allowing them to demand alms by force; it is destroying the right of property (...). Thus the principle of poverty law undermines the foundations of social order"13.

The second consideration is to preserve the legitimacy of the rule of law. In the liberal dogma the law cannot be legitimate unless it aims to ensure freedom but the requirement that the rich help the poor cannot relay on such an idea of freedom.

As a result, the liberalism imposes on the poor to take charge of their fate if they want to improve their destiny. Indeed, "nobody can unload on another the weight of its existence, the twists of fate or misfortune he may suffer "14. As it was summarized

11 Say, J. B. Complete Course of Political Economy. Paris: Brussels, 1843, p. 478.

12 Jourdan, A. French Law. Paris: Plon, 1875, p. 32.

13 Duchatel, T. From Charity in Its Relations with the Moral and Welfare of the Lower Classes of Society. Paris: Mesnier, 1829.

14 Ewald, F. History of the Welfare State. Paris: Grasset, 1986, p. 32. 
by Duchatel in 1829 , you always have to remind the poor that their destiny belongs to themselves. In addition, Duchatel stated: "Never forget: The greatest good you can do to the working classes is to teach them to do without your help"15. It is the same idea which was expressed by Adolphe Thiers (1797-1877) in 1848 after the French Three glorious days. He said: "The fundamental principle of any society is that every man is responsible to provide by himself his needs and his family one's, by resources acquired or transmitted".

Therefore, with liberal dogma, poverty is presumed to reverse itself when its victims have nothing to expect from others or the State. This is also the reason why workers' protection was based on personal or collective protection of private initiative (mutual employees, employer's institutions) until the XXth century.

\subsection{The Hobbesian Conception of Social Contract or the Assistance to the Poor by the State}

On the contrary, the Hobbesian conception of the Social Contract contains the idea of mutual assistance on which the French welfare state is based.

According to Hobbes (1588-1679), by contracting the Social Contract the parties did not intend to ensure their safety only. Admittedly, he did not deny that the subject of this agreement is to establish "a common power, able to defend people from foreign attack and harm they could do to each other" ${ }^{\prime \prime}$. However, it is not limited to this because the assistance of the most disadvantaged is also one of the terms of the contract.

Hobbes stated that "when men become, due to unavoidable circumstances, unable to support themselves through their work, they should not be left to private charity. It's to the laws of the Republic to assist them, to the field required by the necessities of nature. Indeed, if it is a lack of charity for everyone to not worry about invalids, it is also one, from the ruler of a republic to expose them to such an uncertain charity"17. Montesquieu shared the same feeling when he wrote that "Some alms done to a naked man in the streets do not fulfill the obligations of the State since it has to assure to all citizens subsistence, food, proper clothing, and a kind of life that is not contrary to health" 18 .

This idea will be later challenged by Marxism dogma. However, the Hobbesian conception indirectly justifies the advent of the French Welfare State.

\subsubsection{Marxism Dogma}

Since the eve of the French Revolution until the first half of the XIXth century, philanthropic movement was concerned about the effects of the industrialization of

15 Duchatel, T. From Charity in Its Relations with the Moral and Welfare of the Lower Classes of Society. Paris: Mesnier, 1829.

16 Leviathan. Paris: 1971, p. 117.

17 Ibid., p. 369.

18 The Spirit of Laws. 1, 29. 
France on workers. Recognizing that it favors the growth of inequalities, its members, private and policymakers, saw in it a danger for the society. However, the liberals doubted about the part of the virtue of the "invisible hand". J. M. of Gerando (17721842) wrote: "The industry heals the wounds it made. But these results are not absolute and do not take place without the sacrifice of some victims"19. Thus, in the early XIXth century pressure was put on the employers and the State to take more responsibility. Their actions saw few concrete achievements with the creation of gardens and public housing, saving banks, schools and technical rules of distribution of charity. However, it proved to be insufficient to counter the negative effects of industrialization.

In the second half of the XIXth century, the exploitation of man by man became a reality admitted by everyone. It was denounced by writers such as Emile Zola (18401902), for whom capital was "a sort of (...) living God eating the workers in the shadows", and by churchmen such as Pope Leo XIII, who condemned "the concentration" of the wealth "in the hands of few people from the industry and commerce" who profit of it to "impose an almost servile yoke to the infinite variety of proletarians" Karl Marx (1818-1883) who made the most radical criticism.

In The Capital (1867), he did not only condemned the enslavement of the proletariat by the owners of capital, but also saw an insurmountable contradiction between the two groups. It was believed that only the Revolution of the proletariat might terminate this class struggle leading to the disappearance of this instrument of domination in the hands of the bourgeoisie that is the State.

Karl Marx philosophy influenced some politicians, especially under the French Third Republic, and inspired the construction of the welfare state under political and economic points of view.

\subsection{The Political-Economic Justification of the Welfare State}

The political and economic dogmas gave a theoretical foundation to the welfare state, respectively through the idea of Social Democracy and redistributive state .

\subsubsection{The Political Justification: Social Democracy}

The development of the Western Welfare State was favored by the rise of the Social Democracy.

Until 1848 the term was synonymous with Marxism. Thus, the Social Democracy was analyzed as a political doctrine advocating the Revolution as the only way for the proletariat to take power and to end the class struggle, i.e. their enslavement by the bourgeoisie.

But from 1848 the Social Democracy distanced itself from the Marxism. At that time, Marx stated that "a coalition of low bourgeois and workers took off the revolutionary edge of the social demands of the proletariat to give it a democratic turn. It took off the

19 From the public charity. Paris: Hauman 1839, p. 198.

20 Leo XIII, Rerum Novarum. op. cit. 
purely political form of the democratic demands of the low bourgeoisie to add it socialist concerns. Thus was created the Social Democracy."

The originality of this movement in relation to Marxism is, therefore, the rejection of the Revolution as the only means of action. According to this point of view, the Social Democracy appeared as a doctrine of moderation and was considered to be a reformist line. If the market was inevitable, it also created wealth for the Social Democrats and that wealth could be divided according to powerful systems of solidarity to benefit all the members of society.

On the one hand, it is true that the Social Democracy recalls the liberal doctrine, as it accepts the existence of the market. However, it differs from it by entrusting the State with the task of regulating the market in order to fight the inequalities of wealth. In other words, the doctrine is social since it aims to ensure better distribution of wealth and democracy since it accepts political pluralism and the use of universal suffrage. Therefore, it advocates the organization of political parties, which can enable the proletariat to improve its condition, by influencing the appointment of the representatives through election.

This synthesis is the "constitutive compromise of the social State", to which it gave a political base ${ }^{21}$. However, in the XXth century Keynesianism gave it an economic legitimacy.

\subsubsection{The Economic Justification: The State Redistribution}

In relation to economy, the welfare state found a theoretical justification with the work of John Maynard Keynes (1883-1946) and his disciples. For them, states have to try to conciliate three things: economic growth, social justice and individual freedom ${ }^{22}$. But they reject the idea that the nationalization of the means of production and exchange is the only way to fight injustice and irrationality of capitalism.

Noticing the economic impact of consumption of the working classes, they believe that the state can consolidate growth by promoting the maintenance of high consumption. However, according to them, the achievement of this goal requires two things - creating new consumer needs by stimulating investment in research/development and conducting an incomes policy to ensure the purchasing power of the masses (the multiplier principle). It justifies well the intervention of the welfare state since this means that by investing in social policies, the state would only revive the economy.

To prevent loss of control, Keynesians advocate the implementation of countercyclical policies. Such policies tend to stabilize the economy by adjusting spending to the state's prosperity. Thus, in a recession the state should favor cyclical deficits by spending more money than it receives, while, conversely, during periods of growth tax incomers should pay the additional revenue to provisions. In this way, a balanced budget and through it the viability of the welfare state would be guaranteed. In addition, Habermas claimed that "The regulatory State could, through measures to 
stimulate growth on the one hand, the social policy of the other, both supports a strong economy and ensure social integration" ${ }^{23}$.

These different theoretical constructs have certainly influenced and fueled the development of the welfare state. However, primarily it appeared as a sociological reality.

\section{Sociological Roots of the Welfare State}

In practice, two conceptions of the poor relief were introduced from the XVIII ${ }^{\text {th }}$ century till the end of the First World War. These conceptions reflected the clash between two groups in society, which were the ruling elite, which first imposed a bourgeois conception of the poor relief based on liberalism dogma, and the masses, which eventually imposed a more democratic conception.

\subsection{The Earliest Conceptions of the Poor Relief: 1789-1830}

The initial conception of the poor relief can be described as liberal, since it was implemented by the bourgeoisie in power since the Revolution and since it sought to apply the liberal ideas of that time. This conception was prevailing globally in positive law from 1789 until 1830. Thereunder, the old systems of solidarity based on Christian Charity were dismantled without being replaced by the State intervention.

On the one hand, the Revolution removed previous assistance mechanisms. The Church lose a significant portion of its means of intervention because of the nationalization of its property and the declining of its incomes. This was the result of the abolition of privileges by the Decree of August $4^{\text {th }}, 1789$, since their elimination actually put an end to its duty to protect the poor through alms. Meanwhile, by prohibiting corporations, the Le Chapelier Act of June $17^{\text {th }}, 1791$ obliged relief corporations to dissolve and at the same time it forbade them to recreate.

On the other hand, the government was not allowed in anytime to support the poor. The aim was to prevent them from falling into assistantship. It might be possible that the State intended to help people unable to work (children, elderly and the infirm) but the authorities' faith in the liberal dogma gave to this action a form of popular insurance system based primarily on individual initiative. This aspect of the system is highlighted by two of the most important constitutional texts of the French post-revolutionary history:

- Constitution of September 3 $3^{\text {rd }}, 1791$, first title: "It will be created and organized a general establishment of poor relief, to raise abandoned children, relieve the poor infirm, and provide work for able-bodied poor who could not get it by themselves". 
- Constitution of April 11 $11^{\text {th }}, 1848$, Pr, section 7: “Citizens must (...) ensure, through work, livelihoods, and, by the foresight, resources for the future and should contribute to common welfare by helping each other fraternally with each other, and observing general moral laws and written laws that govern society, family and individual".

These statements show that State intervention is secondary, while the first and foremost action is to improve conditions by individuals themselves. The main support systems set up under the influence of these texts reflect this idea.

This is the case of the establishment of public emergency, which was a failure and was limited to "provide work for able-bodied poor" so far as they can justify unsuccessful positive steps of job searching.

This is also the case of saving banks. Historically, their creation aimed to allow the workers to secure their future by accessing their property. But their savings were optional, since they were not obliged to put money aside. It also depended on them to take dispositions for having short-term funds and providing for long-term needs ${ }^{24}$.

It is the case of National administration of retirement, too, since its membership is based on voluntaryism.

Finally, the phrase which summarizes the philosophy that guides the action of the State at that time is to the poor who complain about their fate, the ruling elite responds with Guizot (1787-1874): "Get rich!"25.

Nevertheless, this conception of the poor relief was quickly challenged by the masses.

\subsection{The Popular Conceptions of Poor Relief: 1830-1980}

The second conception of poor relief can be described as popular, since it was designed to satisfy the needs of the disadvantaged masses. From this perspective, it appears to be more democratic.

Described in 1790-1793, it emerged in the 1830s before being completely adopted during the end of World War II. The conception resulted in the recognition of social rights.

In 1790, La Rochefoucauld-Liancourt, a founder of the philanthropic movement, said: "the poor have some rights on the society" ${ }^{26}$. In 1793, the Mountaineers returned to this idea, stating the duty of the State to support the most disadvantaged. They wrote this obligation in the Article 21 of the Declaration of Human and Civil Rights of June $24^{\text {th }}, 1793$ which states: "Public assistance is a sacred debt. Society owes subsistence to unfortunate citizens, either procuring work for them, either by ensuring means of existence to those who are unable to work".

24 Ferrouillat, J. B. Report of the Committee, Work of the Constituent Assembly of 1848, February $19^{\text {th }}$, 1849. Print No. 895.

25 JO Ch. des Députés CR. Session of the March $1^{\text {st }}, 1843$.

26 The $4^{\text {th }}$ Report of the Committee of Begging. August 31 1790. 
Eventually, this idea stopped prevailing because of the spread of the liberal dogma. However, the State finally broke with liberalism to help the most disadvantaged because of the impoverishment of the working classes between 1830 and 1880 (1) and the need to prevent the appearance of a new world war in 1945 (2).

\subsubsection{The Impoverishment of the Working Classes}

The impoverishment of the masses derived from the pauperization of society in the 1830 s and especially from its proletarianization in 1880 .

\subsubsection{Pauperization of the Society}

In 1830, in the Western democracy the "pauperism," a "permanent state of poverty, indigence in a part of society" appeared (Clarendon Press). It was not born out of a lack of work, but of the work itself. It was indeed a consequence of the industrialization of the country, so poverty became a product of the capitalist system.

Given the threat it raised to the future of the society, the State was obliged to remedy the situation by attempting to substitute relief laws to the duty based on the idea of morality. It was reflected in two different ways. Firstly, it was reflected in the apparition of social laws. The Law of March $22^{\text {nd }}, 1841$ on Child Labor ${ }^{27}$ prohibited the exploitation of children under eight years old and limited a work day of children aged 8 to 12 years old to 8 hours per day and a work day of children aged 12 to 16 years old to 12 hours per day (Article 2). However, this limitation must be understood in the light of the requirement made in parallel to the legal guardians of children in school until 12 or until they get their certificate of elementary education (Article 5) because it shows that the aim of the measure was to allow children to raise their living conditions through education. Ultimately, the aim of it was to allow them to support themselves. Through this initiative, the State sought to substitute the private initiative to improve the lives of the unfortunate.

Secondly and most importantly, this evolution is reflected in the creation of an insurance system, which became no longer optional, but mandatory. The idea was to make insurance as a solution against poverty, enabling the poor to protect themselves against the twists of fate in exchange of a small contribution. Various laws have been passed in regard to this goal from year 1850, such as the Law of June $18^{\text {th }}, 1850$ on the Establishment of a National Provident Fund; the Law of July $15^{\text {th }}, 1850$ on the Fraternal Benefit Societies and the Law of April 1 ${ }^{\text {st }}, 1898$ called Charter of Mutuality. These laws gave birth to the so-called "imperial mutuality". Inspired by the Philanthropic society, these imperial mutuality companies were established in order "to incite the workers to gather to ensure resources for illness, or when they would be unable to continue their work due to the infirmities came with age". According to this idea, they were entrusted with the care of old aged and disease risks. They had three advantages that made them the indispensable complement of Saving Banks: their funds were collective, their 
membership was mandatory and the mutualisation of their resources allowed everyone to have the money they needed. In addition, the abovementioned laws opened the way for the first social insurance policies, since social security was becoming a political program in 1852, thanks to Emile de Girardin.

This system was not without interest for the stability of the regime, since the contractual link through the insurance between the citizens and the State was a factor of social peace. As Ferrouillat stated, "Politically speaking, this institution (...) has (...) a (...) great importance" because "it is a guarantee of order and security for the country. It creates between the State and workers a solidarity, a community of interest which can only benefit to the public peace (...). The workman, once entered this vast association, is interested in his entire life to the consolidation of society, the development of public prosperity. His fortune is tied to the State's one. However, the day the man that misery and suffering, exploited by criminal passions, armed against the society will actually believe 'I am the State", that day, you can be confident, citizens, the era of revolution will be closed"28.

The development of this policy was significant since insurance was not the only expression of a practical repair of a risk based on the calculation of probabilities. It was not only a way to "offset the effects of jeopardy by following the laws of statistics" (Albert Chaufton). It is beyond the traduction of the renouncement of the liberal conception of a subjective damage based on the idea of fault in favor of the social conception of an objective damage based on the idea of risk.

\subsubsection{Proletarianization of the Society}

During the second half of the XIXth century, the development of the proletariat led the Western governments to react in order to counter the rise of Marxist ideas. Germany did it by creating the "Sozialstaat" 29 or "social state". In the late XIXth century, Chancellor Otto von Bismarck (1815-1898) assigned to the New German State the mission of promoting the welfare of all its members. He tried to achieve this objective by establishing a social insurance system, covering sickness (1883), workplace fatality (1884), disability and old age (1889). Originally confined to workers, this system was gradually extended to other professions who were found to relate to disadvantaged.

Few years later, French Republic followed a nearly identical approach. Two laws played an additional role in this evolution. These laws were as follows:

- Law of Waldeck of March 21 ${ }^{\text {th }}, 1884$, on the Establishment of Trade Unions, which recognized freedom of association;

- Law of February $11^{\text {th }}, 1892$, on Child Labor, Underage Girls and Women in Industry, which created Labor inspection.

28 Ferrouillat, J. B. Report of the Committee, Work of the Constituent Assembly of 1848, February 19th, 1849 , p. 4.

29 von Stein, L. Der Geschichte von Frankreich Sozialen Bewegung in 1789 Tage bis auf Unsere. Darmstadt: Wissenschaftliche Buchgesellschaft, 1972. 
While the second law gave the means of verifying the respect of its legislation to the State, the first gave to the employees a way to make their demands heard. Combined with the development of Social Democracy and universal suffrage, the abovementioned laws led the government to divide a welfare system into two parts. The first one created a system of public or social assistance through several texts:

- Act of July $15^{\text {th }}, 1893$ on free medical assistance, which ordered to establish annual lists of needy eligible for free caring at home or in hospitals;

- Act of July $7^{\text {th }}, 1889$, which brought the first attack on parental authority in the name of the duty of the State to provide assistance to children;

- Act of July $14^{\text {th }}, 1905$ on assistance to the elderly, the infirm and the incurable.

The second part created a system of social insurance and family benefits through provisions, actions of which were relayed or anticipated by courts:

- Cass. June 21st, 1841: a victim of an accident caused by the lack of security of working conditions may ask his employer for compensation;

- State Council June 21st, 1895, Cames ${ }^{30}$ : the State may ensure its workers against the risk resulting from public duty on the basis of liability without fault. This judgment inspired the legislature in 1898;

- Act of April $9^{\text {th }}, 1898$ about the liability of working accidents;

- Act of May $30^{\text {th }}, 1930$ on social insurance, which provided coverage of old age, sickness, maternity, death and disability;

- Act of March $11^{\text {th }}, 1932$ on family allowances.

The development of the welfare state was also driven by the will of the people and their government to prevent the repetition of World War II.

\subsubsection{The Will to End the War}

45 million victims of World War II led some Western governments to try to establish institutions necessary to prevent the repetition of history. Thus, the Atlantic Charter of August 14 $4^{\text {th }}$, 1941, drafted by Franklin Delano Roosevelt (1882-1945) and Winston Churchill (1874-1965). promised "improvement of working conditions, economic progress and social security"(Art. 5). Two considerations were thought of when creating the Charter..The first is the origin of the War of 1939-1945. Its run was facilitated by the consequences of the crisis of 1929. By multiplying the number of the unemployed, it increased the tension within the society which allowed Adolf Hitler to come to power. However, he had cemented his popularity on social legislation ahead of the one of the Western States ${ }^{31}$. Therefore, they found it necessary to increase social protection at the end of the war in order to avoid further divisions within the nation.

The second reason was linked to the consequences of the war itself. Given the number of the dead and the mutilated with special needs or unable to work, states could hardly stay inactive.

30 Rec. CE, p. 509.

31 William, P. Birth of the Welfare State. Rev. Ec. 2000, 51(2): 373-379. 
Internationally, the Atlantic Charter gave birth to large international organizations that formed the UN. While World Health Organization aims to improve health conditions internationally, the World Bank seeks to organize a pension system based on international savings and private insurance and the International Labour Organization aims to "improve the fate of workers" throughout the world by promoting "humane conditions of labor" inspired by "social justice" 32 .

Internally, it inspired two new forms of struggle against poverty and exclusion. The first, inspired by the work of Keynes, appeared in England in 1942 in the report of William Beveridge (1879-1963) entitled "Social Insurance and Allied Services". It related to the concept of the "welfare State" (William Temple, 1943) as opposed to the "Warfare State" which distinguished itself during the war. The originality of the mechanism which Beveridge advocated was the rejection of a system of social insurance and public assistance respectively reserved exclusively to workers and the poor. Instead, he advocated a universal welfare system financed by taxes and benefiting all citizens. In fact, the report by Beveridge was in favor of a social security system which was generalised, unified, uniform, centralized and global. Each of these five characteristic could be explained as follows:

- Generalized: each person, due to his/her membership in the society, is entitled to have his/her minimum needs guaranteed by the national solidarity;

- Unified: one fee is required to access various services, which can come in a form of fringe benefits or cash allowances;

- Uniform: social benefits are the same for all people;

- Centralized: the system is managed by a single public body;

- Overall: the system includes all the aid and insurance.

The second form of social security appeared in France after the war. During the conflict, the National Council of Resistance announced its intention to establish "a comprehensive social security, to ensure all citizens livelihoods". On April $10^{\text {th }}, .1945$ lawyer Pierre Laroque tried to realize this goal. He reaffirmed the idea that "the French social policy (...) must (...) seek to build a new social order, focused (...) to make social security, that is to say to ensure all members of the population that they will enjoy in all circumstances sufficient income for their livelihood Family"33. Thus, the Law No. 46-1146 of May $22^{\text {nd }}, 1946$ on the general social security created a universal system of social security based on the right of "any French" to "benefit the legislation on social security "(Article 1). The originality of the system was to finally synthesize former French insurance protection and English universal protection, the Bismarckian system based on employer and employee contributions and the Beveridge system based on tax ${ }^{34}$. From the first synthesis, it inherited the logic of the system financed by contributions from workers, jointly managed by unions and employers, while from the second one it

32 ILO Constitution of 1919, Preamble.

33 Laroque, P. The French Social Security Plan. French Review of Labour. 1946: 9-10.

34 Majnoni of Intignano, B. Social Protection. Paris: LGF, 1993. 
inherited the idea of a generalized social security system, which was centralized and global.

This system eventually developed with the creation of unemployment insurance. It appeared in 1957 with the creation of ASSEDIC and UNEDIC ${ }^{35}$ and was consolidated with the creation of the National Fund for Employment in $1963^{36}$ and the National Agency for Employment in $1967^{37}$.

The existence of this protection scheme was implicitly guarantied by the French Constitution of October $27^{\text {th }}, 1946$, as its preamble stated in the paragraph 11: “- (...) Every human being who, because of his age, physical or mental condition, the economic situation, is unable to work has the right to obtain the community suitable means of existence". The Constitution of April 10 19 th 1958 confirmed this evolution in the Article 1 by stating that "France is a social Republic". Through this constitutionalism, the existence of the welfare state was established.

The emergence and development of the welfare state was a clear progress because "for the first time, capitalism, rather than thwart the Republican promise of equal rights for all citizens, made it possible" 38 . Yet the development of the crisis and the rising of neoliberalism jeopardized this progress.

\section{Conclusions}

In 1981 an OECD report entitled The Crisis of the Welfare State raised the question whether the French welfare state was a "giant social" with "feet of clay" 39 According to the report, this crisis was effective and legitimate.

Firstly, it was the crisis of effectiveness, because its redistribution did not prevent increase in inequalities and emergence of new forms of exclusion. Indeed, for "the welfare State" the "only answer for exclusion is individual financial compensation" 40. However, it was not the right answer since disadvantaged people cash the money without finding their place in the society.

Secondly, it was the crisis of legitimacy due to the tax burden on households. State intervention in economy favoured redistribution of income through a significant increase in the tax. Representing 10\% of Gross Domestic Product in the early XXth century, it increased more than 50\% in some European countries in the $1980 \mathrm{~s}$. At that time, however, the very existence of the welfare state was questioned because of the increasingly significant financial effort, as its funding requested national solidarity. Therefore, the right question had to be what level was below which people will not accept to fund social spending anymore.

35 Agreement of December $31^{\text {th }}, 1958$.

36 Law No. 63-1240 of December 18 ${ }^{\text {th }}, 1963$ on the National Employment Fund.

37 Ord. No. 67-578 of July 13 ${ }^{\text {th }}, 1967$, establishing a National Employment Agency.

38 Habermas, J. After the Nation-State. Paris: Fayard, 2000, p. 128.

39 Bebear, C. Less Government. Powers. 94: 121.

40 Sadoun, M. The Individual and the Citizen. Powers. 94: 10. 
This crisis had several causes, effects of which combined ${ }^{41}$. Some of them were institutional, which were due to the deficit of the social representation. It was related to the desecration of major institutions, in particular the weakening of traditional political parties and the emergence of private decision-makers, such as associations or multinational firms. However, the more serious causes were economic and ideological. While the first cause resulted from the decline in population and the development of globalization, the second one resulted from the rising of neo-liberalism.

In 1970-1980s the welfare state was subject to the repeated attacks from the neoliberals. Led by Friedrich Hayek (1899-1992) ${ }^{42}$ and Milton Friedman (1912-2006) ${ }^{43}$, the neoliberals rejected the Keynesian dogma because of the revival of the classical liberal theory. According to them, the state intervention was bad because it was distorted without any reasonable competition.

This criticism echoed in a certain number of discussion forums. Some forums were founded by the civil society, such as the Mont Pelerin Society, which Hayek created in the end of World War I, and the Davos forum created in 1971 by the Klaus Schwab Foundation to allow private decision-makers to share their expectations with policymakers. Other forums were founded based on the initiative of the states themselves, such as the International Financial Institutions (IMF, WB), the G7 and G8 or the OECD.

The above mentioned forums gave birth to an «intellectual orthodoxy» making liberalism the only viable economic system in a globalized economy. This international pressure led states to review their interventionist policies. The idea triumphed as a «part of a global economy, the States can not improve the competitiveness of their economy without reducing their administrations. «Policies of 'dismantling'» were thus justified despite their bad «effect» on «social solidarity» and «the democratic stability of the society» ${ }^{44}$. Thus, «social disinflation» was the cost of the competitiveness increase ${ }^{45}$.

It is possible that this disinflation was more or less important depending on the country. However, if it was marked in Anglo-Saxon countries, it became more and more important in European ones.

So far, the question is not if the welfare state is in crisis or not because now a consensus exists on this point. However, others questions still remain, such as whether the dismantling of social protection systems is the condition of the growth return ${ }^{46}$ and whether it is possible to aid unemployment without digging national deficits, and to share growth gains without weakening it. On the other hand, and most importantly, the question remains whether the society is doing well without a welfare state doomed to implode? The answer to the latter question could be positive because without effective social justice, social ties disintegrate. Thus, if the welfare state has to be reformed due

41 Cole, A. Networks and the Public Sphere. Lessons from France and Britain. In Francis B. \& Neveu, E. Public Spaces. Rennes: PUR, 1999, p. 250.

42 The Road to Serfdom. Paris: Médicis, 1946; Law, Legislation and Liberty. Paris: PUF, 1980; The Constitution of Liberty. Paris: Litec, 1994.

43 Capitalism and Freedom. Paris: Laffont, 1962; Freedom of Choice. Paris: Belfont, 1980.

44 Habermas, J. After the Nation-State. Paris: Fayard, 2000, p. 30.

45 Mauroy, P. The Future of the Welfare State. Paris: L'Ours: p. 12.

46 Ibid., p. 12. 
to new economic constraints resulting from the globalization, its existence cannot be threatened. The first reason for that could be the fact that the state intervention reflects a social demand. In 1992, 66\% of EU citizens were positive about the continuation of social security benefits, even if the cost of a tax burden increased ${ }^{47}$. Therefore, actions led by the ILO in favor of the improvement of the workers' fate primarily reflect the aspiration of individuals to "give a human face to the globalization"

The second reason could be subprime crisis showing that the state intervention is necessary since the self-regulation of the market is a myth. Therefore, "high performing Asian economies" (HPAE: Japan, Hong Kong, China, Taiwan, South Korea and Indonesia) are seen as those, which succeeded in mixing "quick economic growth" and "social justice", e,g, through "land reforms". Indeed, tt is created "by investing in people, their education, their technical competence and their health, that HPAE won their current status"49.

Some people would state that the alternative is to either level social protection from above by requiring developing countries to adopt a social system similar to the one of the Western countries or by forcing rich countries from the bottom to dismantle their welfare system to reduce it to a "safety net" $" 50$ close to that of the countries developing. Neo-liberalism pushes in the latter direction and social democracy in the former one.

However, other people would state that between the status quo and reflux, inaction or abandonment of social benefits different options are available to policymakers. There is, indeed, a "third way" 51 between maintaining or dismantling the welfare state ${ }^{52}$. The solution may exist in the appearance of a "welfare mix", a "smart" welfare state 53 characterized by a more rational and, therefore, respectful intervention on the market. It is also possible that the creation of an international or, at least, European Tobin tax may be a good way to solve the problem links to the funding of the welfare state.

Some politicians have laid the foundations for such a third way by creating the concept of Social-liberalism. Thus, in 1997 the Labour party member Tony Blair denounced "welfare State laxism" and asked "social assistance beneficiaries" for accepting all "adequate offers of employment". Similarly, in 1998 the Social Democrat Gerhard Schröder said it was "more important to fund the work" than to "pay unemployment". They were in favour of sanctions against the unemployed who lived from assistantship. Moreover, by abandoning the revolutionary perspective of Marxism and the idea of the State's disparition, the Social-liberalism is characterized by the condemnation of those who abuse the system.

47 Chassard, Y. Social Protection in Europe. The Future of the Welfare State. Paris: L'Ours, p. 110.

48 Laroque, M. Administration of Welfare State. Powers. 94 (72).

49 Meghad. The East Asian Miracle East: Economic Growth and Public Policy. Report of the World Bank. Washington: 1993, p. 132.

50 Desai, M. The Welfare State in Asia. The Future of the Welfare State.Paris: L'Ours, p. 130.

51 Ferrera, Redesigning European Welfare States. Powers. 94 (104).

52 Ibid., p. 107.

53 Hewitt, P. \& Miliban, D. National Social Policy: Opportunities and Constraints. The Future of the Welfare State. Paris: L’Ours,,p. 66. 
The question may arise where the balance point between the fight against the assistantship and maintaining of the redistributive nature of the welfare state exists. The question could be undeniably answered by those, who challenge European politicians in the early XXIst century.

\section{Bibliography}

Agreement on the Creation of ASSEDIC and UNEDIC of December 31st, 1958.

Bebear, C. Less Government. Powers. 94. CE, July 21st, 1895, Cames, Rec. CE, p. 509.

Chevallier, J. The Post-Modern State. Paris: LGDJ, 2004.

de Gerando, J. M. From the Public Charity. Paris: Hauman, 1839.

Duchatel, T. From Charity in Its Relations with the Moral and Welfare of the Lower Classes of Society. Paris: Mesnier, 1829.

Ewald, F. History of the Welfare State. Paris: Grasset, 1996.

Ferrera, M. Redesigning European Welfare States. Powers. 94.

Ferrouillat, J. B. Work of the Constituent Assembly of February $19^{\text {th }}$ 1848. Report of the Committee. 1849, 895.

Fondation, J. J. The Future of the Welfare State. Paris: L'Ours, 1995.

Foucault, M. History of Madness. Paris: Plon, 1961.

Francis, B. \& Neveu, E. Public Spaces. Rennes: PUR, 1999.

Friedman, M. Capitalism and Freedom. Paris: Laffont, 1962.

Friedman, M. Freedom of Choice. Paris: Belfont, 1980.

Habermas, J. After the Nation-State. Paris: Fayard, 2000.

Hauriou, M. Note under TC of September 12th, 1899. Assoc. Synd. du Canal de Gignac, Paris. Dalloz. 1899 (3) : 50.

Hayek, F. The Road to Serfdom. Paris: Médicis, 1946.

Hayek, F. Law, Legislation and Liberty. Paris: PUF, 1980.
Hayek, F. The Constitution of Liberty. Paris: Litec, 1994.

Hobbes, T. Leviathan.

ILO Constitution of 1919, Preamble.

Paris: JO Ch. de Député CR, Session of May 18th, 1893 .

Paris: JO Ch. des Députés CR, Session of March $1^{\text {st }}, 1843$.

Jourdan, A. French Law. Paris: Plon, 1875.

Keynes, J. M. The End of Laissez-Faire. London: Woolf, 1926.

Lacroix, P. What Is the Divine Providence. Paris: City of the Father, 2005.

Laroque, M. Administration of Welfare State. Powers. 94

Laroque, P. The French Social Security Plan. French Review of Labour. 1946.

Law No. 63-1240 of December 18th,1963 on the National Employment Fund.

Law of March 22nd, 1841 on Child Labor. Bull. l., 1841, 795. Text No. 9203

Leo XIII. Rerum Novarum. May 15th,1891.

von Stein, L. Der Geschichte von Frankreich Sozialen Bewegung in 1789 Tage Bis auf Unsere. Darmstadt: Wissenschaftliche Buchgesellschaft, 1972.

Majnoni d'Intignano, B. Social Protection. Paris: LGF, 1993.

The East Asian Miracle East. Report of the World Bank. Washington: 1993.

Montesquieu. The Spirit of Laws.

Morand, C. A. Weighing Global Interests. Bâle: Helbing \& Lichtenhahn, 1996.

Ordonnance No. 67-578 of July 13th, 1967, establishing a National Employment Agency.

Sadoun, M. The Individual and the Citizen. Powers. 94. 
Say, J. B. Complete Course of Political

Economy. Paris: Brussels, 1843.

St Thomas. Are Theological.

The $4^{\text {th }}$ Report of the Committee of Begging.

Paris: 1790.
William, P. Birth of the Welfare State. Rev. Ec. 2000, 51(2).

\section{PRANCŪZIJOS GEROVĖS VALSTYBĖS SAMPRATOS IŠTAKOS}

\section{Fabien Bottini}

Le Havre universitetas, Prancūzija

Santrauka. Kokios yra geroves valstybes istakos? Prancüzijos atvejo tyrimas parodo, kad keletas iš priežasčiu yra ideologinio, o kitos - sociologinio pobüdžio.

Ideologines ištakos kildinamos iš socialistiniu ideju. Vis delto ne iš identišku toms, kurios buvo pristatomos didžiausiu ideologiniu revoliuciju metu. Kai kurios ju yra religinio pobüdžio ir ju ištaku reikètu ieškoti krikščioniškosios labdaros katalikiškoje koncepcijoje bei protestantiskoje pagalbos koncepcijoje. Kitos prielaidos yra filosofinès kilmés ir susijusios taip pat ir su marksistine teorija bei prigimtines teises dogma. Taip pat reiketu pridurti, kad Loko socialines sutarties koncepcija smerkè valstybès pagalba vargingiausiems piliečiams. Hobso idèjos, priešingai - skelbè, kad tokia pagalba yra valstybès pareiga. Kitos prielaidos yra politinès ir kilo kartu su socialines demokratijos vystymusi, kuri yra ginanti politines partijas, kurios suteikia proletariatui galimybes pagerinti savo padèti darant ịtaka rinkimu metu renkant atstovus. Kitos prielaidos yra ekonominio pobüdžio ir susijusios su keinsizmu, kai valstybei patikima misija skatinti augima, iš vienos puses, o is kitos pusès, vykdyti socialine politika, tuo remiant stipriq ekonomika ir užtikrinant socialine integracija.

Kaip bebütu, vien ideologines idejos negaletu pateisinti valstybès transformacijos i geroves valstybę, jei nebütu tam socialinès paklausos. Tuo labiau, kad Vakaru populiaciju nuskurdimas 18 a. pradžioje kartu su industrinemis revoliucijomis ipareigojo politines jegas vystyti socialine politika ir užtikrinti visuomenés stabiluma. Šis poreikis tapo dar aktualesnis po Antrojo pasaulinio karo, kai kilo bütinumas užkirsti kelia naujų konfiktu kilimui.

Gerovès valstybès koncepcijos populiarumas rodo, jog ji neatsiejamai susijusi su demokratinès valstybès samprata. Globaliame pasaulyje užduodamas klausimas dèl pagalbos ir paskirstomosios gerovés valstybès paskirties pusiausvyros ǐsangojimo. Šis klausiams lieka prioritetinis ir Europos politikams 21 a. pradžioje.

Reikšminiai žodžiai: kontroliuojanti valstybè, gerovès valstybè, Etat-Providence, socialine valstybè, perskirstanti valstybè, socialines teises.

Fabien Bottini, Havro universiteto Tarptautinių santykių fakulteto Teisès katedros mokslininkas, viešosios teisès daktaras; Prancūzų teisès laboratorijos LexFEIM narys ir „Large-scale Research Network: Culture and Society in Normandy“ narys. Tyrimų kryptys: administracinè teisè, konstitucinė teisè, visuomeninès laisvès. 
Fabien Bottini, Le Havre University, Faculty of International Affairs, Department of Law, Doctor in Public Law; Member of the French Laboratory of Law LexFEIM and the GRR Culture and Society in Normandy. Research interests: Administrative Law, Constitutional Law and Public Liberties. 